\title{
Sistem Informasi Penjualan Perlengkapan Bayi Pada Toko Dewa Kembar Baby Shop Jakarta
}

\author{
Taufik Baidawi ${ }^{\mathbf{1}}$, Nadia Saras Dwiyanti ${ }^{2}$ \\ ${ }^{1}$ Fakultas Teknologi Informasi, Program Studi Sistem Informasi, Universitas Bina Sarana Informatika \\ e-mail: taufiq.tfb@bsi.ac.id \\ ${ }^{2}$ Program Studi Sistem Informasi, STMIK Nusa Mandiri \\ e-mail: sarasnadia12@gmail.com
}

\begin{abstract}
Abstrak - Pada saat ini,perkembangan teknologi dan informasi membawa dampak yang luar biasa dalam berbagai bidang. Internet adalah suatu jaringan komputer yang satu dengan yang lain saling berhubungan untuk keperluan komunikasi dan informasi. Toko Dewa Kembar Baby Shop adalah toko yang bergerak dibidang penjualan keperluan bayi. Seperti popok, dot, baby walker, baby stroller, kolam renang portable dan lain-lain. Artinya pelanggan harus mendatangi toko untuk dapat melakukan pembelian produk. Pembangunan Sistem informasi penjualan perlengkapan bayi berbasis web pada Toko Dewa Kembar Baby Shop merupakan langkah untuk meningkatkan penjualan dan promosi produk sehingga dapat memberikan keuntungan bagi toko. Tujuan pembangunan system informasi penjualan keperluan bayi pelanggan dapat melakukan pemesanan produk tanpa harus datang ke toko, pihak toko pun dapat mengatasi masalah pengolahan produk, pengolahan pemesanan. Sehingga memberikan kemudahan kepada konsumen untuk mendapatkan informasi tentang produk perlengkapan keperluan bayi. Sistem ini dibuat menggunakan program Php dan Database MySql serta menggunakan editor Dreamweaver. Dengan diimplementasikannya sistem informasi penjualan keperluan bayi berbasis web pada Toko Dewa Kembar Baby Shop ini dapat digunakan sebagai sarana promosi penjualan, proses pembelian dapat secara langsung tanpa harus datang ke toko, serta dapat mempermudah transaksi pembelian produk.
\end{abstract}

Kata Kunci: Sistem Informasi Penjualan; Berbasis Web; Toko Perlengkapan.

Abstrac - At this time, the development of information technology brings a tremendous impact in various fields. Internet is a computer network with one another interconnected for communications and information. Shop Dewa Kembar Baby Shop is engaged in the sale of baby needs. Such as diapers, pacifiers, baby walker, baby stroller, portable swimming pools and others. This means that customers have come to the store to make a purchase of products. Development Sales information system Web-based baby gear store Dewa Kembar Baby Shop is a step to increase sales and promotion of products that can provide benefits to the store. The development objective for the baby sales information system customers can order products without having to come to the store, the store can solve the problem of product processing, order processing. Thus providing convenience to consumers to get information about product supplies baby needs. This system is created using PHP and MySql Database and use Dreamweaver editor. With the implemented system sales information a web-based on store Dewa Kembar Baby Shop baby can be used as a means of sales promotion, the purchase process can be directly without having to come to the store, and can facilitate the purchase of products.

Keywords Sales Information Systems; Web-Based; Store Fixtures.

\section{PENDAHULUAN}

Sejalan dengan berkembangnya dunia teknologi dan komputer yang begitu pesat pada saat ini yang secara tidak langsung mempengaruhi kebutuhan hidup manusia, khususnya teknologi yang berbasis komputer menyebabkan kebutuhan informasi pun semakin meluas. Salah satu cara untuk mendapatkan informasi adalah dengan memanfaatkan internet. Manfaat internet adalah dapat menghemat ruang dan waktu sehingga informasi yang diinginkan dapat ditemukan tanpa harus meninggalkan tempat dan aktivitas rutin kita. Internet merupakan salah satu media elektronik yang memberi kemudahan dan informasi dalam melaksanakan aktivitas-aktivitas, bisnis, perniagaan dan aktivitas lainnya, oleh karena itu pada era sekarang ini banyak perusahaan yang telah memanfaatkan jasa pelayanan internet untuk menunjang kegiatan bisnisnya.

Untuk mempercepat dan meningkatkan penjualan secara cepat maka dapat dengan memanfaatkan teknologi informasi yang sangat pesat tersebut yakni dengan layanan secra on-line berupa transaksi e-commerce. Selama ini, sistem penjualan dari pelanggan yang digunakan oleh bersifat manual, sehingga memiliki potensi kesalahan lebih besar. Dengan adanya layanan jasa berupa e-commerce yang dapat secara cepat dapat dinikmati oleh pelanggan maupun perusahaan sendiri maka segala 
layanan yang diinginkan oleh para pelanggan dapat segera ditindak lanjuti dengan secepat mungkin, sehingga perusahaan tersebut akan mampu memberikan pelayanan yang terbaik dan tercepat bagi para pelanggan (Fathansyah, 2012).

\section{METODE PENELITIAN}

\section{A. Metode Penelitian}

Metode pengumpulan data yang dilakukan meliputi observasi, wawancara, dan studi pustaka, dapat dijelaskan sebagai berikut:

1. Observasi (Observation)

Melakukan pengamatan langsung terhadap kegiatan penjualan alat-alat perlengkapan Bayi pada Toko Dewa Kembar Baby Shop sehingga memperoleh sejumlah data mengenai kegiatan penjualan alat-alat perlengkapan bayi yang masih secara manual.

2. Wawancara (Interview)

Melakukan tanya jawab dengan Bapak Bahrun Sebagai Manajer Penjualan, Ibu Rohma dan beberapa orang narasumber ditempat atau lokasi dimana objek penelitian dilakukan.

3. Studi Pustaka (Literature)

Melakukan studi pustaka, penulis melakukan studi dari beberapa literatur yang berisi teoriteori yang berkaitan dengan jurnal penelitian terkait. Selain itu referensi juga diperoleh dari beberapa jurnal ilmiah yang relavan dengan permasalahan yang dibahas dalam penelitian.

\section{B. Model Pengembangan Sistem}

\section{a. Analisis Kebutuhan Sistem}

Pada tahap ini penulis mempelajari dan memahami tentang permasalahan dan hal-hal yang berkaitan dengan membangun sistem web ecommerce selama melakukan penelitian di Toko Dewa Kembar Baby Shop. Dari pemahaman tersebut maka penulis menggunakan bahasa pemograman $P H P$ yang merupakan salah satu bahasa pemograman yang banyak digunakan dalam pengembangan web, dengan database yang dipakai adalah Mysql, dan desainnya dengan menggunakan Adobe Dreamweaver. Alat yang digunakan untuk menunjukan proses dan aliran data yaitu spesifikasi data dan $U M L$.

\section{b. Desain}

Desain dan pembuatan program berkonsentrasi pada bagaimana sistem dibangun untuk memenuhi kebutuhan pada fase analisis, membangun perangkat lunak untuk mendukung sistem dengan menggunakan UML, desain database dengan menggunakan ERD dan LRS, manajemen user, modul-modul pada web, konten atau isi web manajemen database serta membangun user interface.

\section{c. Code Generation}

Pada tahapan ini penulis menggunakn bahasa pemograman bahasa pemrograman Hipertext Prepocessor (PHP), Mysql, Adapun sistem yang dibangun termasuk kedalam pemograman terstruktur.

\section{d. Testing}

Pada penelitian ini peneliti menggunakan pengujian eksternal (Black Box) dengan melakukan pengujian terhadap aplikasi dengan cara mengecek satu persatu link dengan menggunakan tabel pengujian, apakah link tersebut tersebut sudah mengandung tingkat validasi yang benar dan optimal. Hal ini dilakukan untuk meminimalisir kesalahan (error) dan memastikan keluaran yang dihasilkan sesuai dengan yang diinginkan.

\section{e. Support}

Pada tahap ini dilakukan pemilihan spesifikasi support software dan hardware untuk mendukung program adapun yang digunakan yaitu: Microsoft Windows 7 Ultimate 64-Bit, Appachetriad, Macromedia Dreamweaver, PHP MySQL dan Hardware meliputi: processor, memory, monitor, hard disk, keybord, mouse, dan printer.

\section{Konsep Dasar Model Pengembangan Sistem}

Model System Development Life Cycle (SDLC) air terjun (waterfall) sering juga disebut model sekuensial linear (sequential linear) atau alur hidup klasik (classic life cycle). Model air terjun menyediakan pendekatan alur hidup perangkat lunak secara sekuensial atau terurut dimulai dari analisis, desain, pengodean, pengujian, dan tahap pendukung (support) (Handita, Umar, \& Fadillah, 2014).

1. Requirement analysis and definition

Proses mengumpulkan apa yang dibutuhkan secara lengkap untuk kemudian dianalisis guna mendefinisikan kebutuhan yang harus dipenuhi oleh program yang akan dibangun. Fase ini harus dikerjakan secara lengkap untuk bisa menghasilkan desain yang lengkap.

2. System and software desain

Proses setelah apa yang dibutuhkan selesai dikumpulkan dan sudah lengkap maka desain kemudian dikerjakan. Proses multi langkah yang fokus pada desain pembuatan program perangkat lunak termasuk struktur data, arsitektur perangkat lunak, representasi antarmuka, dan prosedur pengkodean.

3. Implementation and unit testing

Desain program diterjemahkan ke dalam kodekode dengan menggunakan bahasa pemograman yang sudah ditentukan. Program yang dibangun langsung diuji secara unit, apakah sudah bekerja dengan baik.

4. Integration and system testing

Penyatuan unit-unit program untuk kemudian diuji secara keseluruhan (system testing). 


\section{Operation and Maintenance}

Mengoprasikan program dilingkungannya dan melakukan pemeliharaan, seperti penyesuaian atau perubahan untuk adaptasi dengan situasi yang sebenarnya.

\section{Pengujian Web}

Black box testing adalah tipe testing yang memperlakukan perangkat lunak yang tidak diketahui kinerja internal nya. Sehinga para tester memandang perangkat lunak seperti layaknya sebuah "kotak hitam" yang tidak penting dilihat isinya, tapi cukup dikenal proses testing dibagian di bagian luar" (Fowler, 2018).

Jenis testing ini hanya memandang perangkat lunak dari sisi spesifikasi dan kebutuhan yang telah didefinisikan pada saat awal perancangan. Maka pada jenis white box testing, perangkat lunak tersebut akan berusaha dibongkar listing programnya untuk kemudian di tes menggunakan teknik-teknik yang telah dijelaskan sebelumnya. Sedangkan pada jenis black box testing, perangkat lunak tersebut akan dieksekusi kemudian berusaha di tes apakah telah memenuhi kebutuhan pengguna yang didefinisikan pada saat awal tanpa harus membongkar listing programnya. Keuntungan yang diperoleh dari jenis testing ini antara lain:

1. Anggota tim tester tidak harus dari seseorang yang memiliki kemampuan teknis di bidang pemrograman.

2. Kesalahan dari perangkat lunak ataupun bug seringkali ditemukan oleh komponen tester yang berasal dari pengguna.

3. Hasil dari black box testing dapat memperjelas kontradiksi ataupun kerancuan yang mungkin timbul dari eksekusi sebuah perangkat lunak.

4. Proses testing dapat dilakukan lebih cepat dibandingkan white box testing.

\section{ERD (Entity Relationship Diagram)}

"Merupakan model entity relationship yang berisi komponen-komponen himpunan entitas dan himpunan relasi yang masing-masing dilengkapi dengan atribut-atribut yang merepresentasikan seluruh fakta dari dunia nyata yang kita tinjau, dapat digambarkan dengan lebih sistematis dengan menggunakan diagram entity relationship (diagram E-R)”.(Anhar, 2010), (Sukamto, 2014).

Komponen-komponen yang terdapat dalam ERD adalah notasi ERD, Cardinality Ratio, Derajat Relationship. (Mulyanto, 2008).

a. Notasi dan Simbol ERD

1) Entity

Entity adalah sesuatu yang dapat dibedakan dalam dunia nyata dimgna. informasi yang berkaitan dengannya dikumpulkan. Simbol yang digunakan untuk entity adalah persegi panjang.

2) Relationship
Relationship adalah hubungan yang terjadi antara satu atau lebih entity. Simbol yang digunakan adalah belah ketupat, atau rectangle.

3) Atribute

Atribute adalah karakteristik dari entity atau relationship yang menyediakan penjelasan detail tentang atau relationship tersebut.

\section{b. Cardinality Ratio}

Cardinality Ratio atau mapping cardinality adalah menjelaskan hubungan batasan jumlah keterhubungan satu entity dengan entity lainnya atau banyaknya entity yang bersesuaian dengan entity yang lain melalui relationship. Jenis cardinality Ratio:

1) One to one (1:1) yaitu hubungan satu entity dengan satu entity.

2) One to Many (M:N) atau Many to One (M:1) yaitu hubungan satu entity dengan banyak entity atau banyak entity dengan satu entity.

3) Many to Many (M:N) yaitu hubungan banyak entity dengan banyak entity.

c. Derajat relationship

Derajat relationship menyatakan jumlah entity yang berpartisipasi di dalam suatu relationship.

1) Unary degree (derajat satu) yaitu derajat yang memiliki satu relationship untuk dua buat entity.

2) Binary degree (derajat dua) yaitu derajat yang memiliki satu relationship untuk dua buah entity.

3) Ternary degree (derajat tiga) yaitu derajat yang memiliki satu relationship untuk tiga atau lebih entity.

\section{d. Participation constraint}

Participation constraint menjelaskan apakah keberadaan suatu entity tergantung pada hubungannya dengan entity lain. Terdapat dua macam participation constrain, yaitu:

1) Total Participation, yaitu keberadaan suatu entity tergantung pada hubungannya dengan entity lain.

2) Partial Participation, yaitu keberadaan suatu entity tidak tergantung dengan entity lain.

\section{E. UML (Unfied Modelling Language)}

Merupakan keluarga notasi grafis yang didukung oleh meta-model tunggal, yang membantu pendeskripsian dan desain sistem perangkat lunak, khususnya sistem yang dibangun menggunakan pemrograman berorientasi objek (OOP). (Arief, 2012), (Riyanti \& Baidawi, 2015)

UML merupakan standar yang relatif terbuka yang dikontrol oleh Object Management Company (OMG), sebuah konsorsium terbuka yang terdiri dari banyak perusahaan.

\section{Use Case Diagram}

Use case adalah teknik untuk merekam persyaratan fungsional sebuah sistem. Use case mendeskripsikan interaksi tipikal antara para pengguna sistem dengan sistem itu sendiri, 
dengan memberi sebuah narasi tentang bagaimana sistem tersebut digunakan. Use Case Diagram menampilkan aktor mana yang menggunakan use case mana, uses case mana yang memasukkan use case lain dan hubungan antara aktor dan use case. (Arief, 2012), (Kosasi, 2015)

\section{Activity Diagram}

Activity diagram menggambarkan workflow (aliran kerja) atau aktifitas dari sebuah sistem atau proses bisnis atau menu yang ada pada perangkat lunak. Activity diagram merggambarkan aktivitas sistem bukan apa yang dilakukan aktor, jadi aktivitas yang dapat dilakukan oleh system. (Handita et al., 2014)

\section{Component Diagram}

Component Diagram memperlihatkan organisasi serta ketergantungan sistem/ perangkat lunak pada komponen-komponen yang telah ada sebelumnya. (Handita et al., 2014)

\section{Deployment Diagram}

Deployment Diagram menunjukkan konfigurasi komonen dalam proses eksekusi aplikasi.(Irmawati, 2011)

\section{HASIL DAN PEMBAHASAN}

\section{A. Analisa Sistem Berjalan (Proses Bisnis Sistem)}

Sistem penjualan yang berjalan pada toko Dewa

Kembar Baby Shop mempunyai dua tahapan, yaitu Pelanggan dapat memesan barang melalui datang langsung ke toko. Pelanggan memilih barang apa yang akan dibeli, pelanggan melakukan transaksi pembayaran atas barang yang dibeli kepada kasir, berupa uang sebagai bukti pembayaran yang sah. Kemudian kasir akan membuatkan nota pembelian untuk diberikan kepada pelanggan sebagai bukti bahwa barang yang telah diberi tersebut telah dibayar. Bagian kasir mengambil data-data penjualan dari rekap nota penjualan dan membuat laporan penjualan bulanankemudian disampaikan kepada pemilik toko.

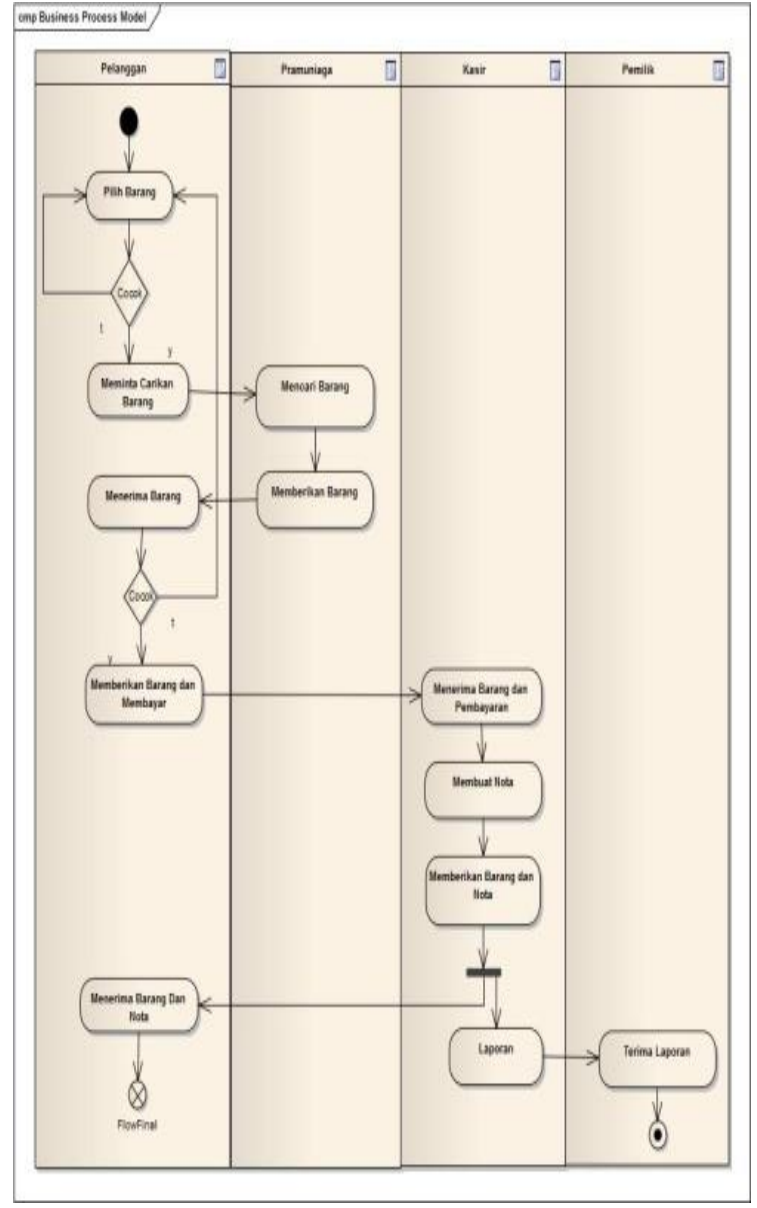

Gambar 1.

Activity Diagram Proses Pemesanan

\section{B. Tahapan Analisis}

Sistem Informasi Penjualan Perlengkapan bayi Berbasis Web Pada Toko Dewa Kembar Baby Shop mencangkup kegiatan yang dapat dilakukan user, member dan admin tanpa harus bertatap muka, melainkan melalui media website secara online. Berikut ini spesifikasi kebutuhan (system requirement) dari sistem penjualan perlengkapan bayi dengan fasilitas transaksi secara transfer online dimana member dan kasir tidak perlu bertatap langsung untuk melakukan suatu transaksi. Member mendapatkan informasi penjualan produk melalui media browser. Berikut spesifikasi kebutuhan (system requirement) dari sistem penjualan perlengkapan bayi berbasis web dengan fasilitas Transaksi online.

Halaman Front-page untuk User

A1. User dapat mendaftar sebagai member pada menu daftar.

A2. User dapat melihat beranda website.

A3. User dapat melihat produk - produk yang dijual.

A4. User dapat melihat testimoni.

A5. User dapat melihat tentang Perusahaan.

A6. User dapat melihat informasi. 
Halaman Member:

B1. Member dapat login dengan account yang telah dibuat

B2. Member dapat melihat beranda.

B3. Member dapat memilih produk dan memesan produk, dapat mengupdate keranjang belanja, melanjutkan belanja dan mengisi data pengiriman, lalu mencetak bukti transaksi.

B4. Member dapat memfilter produk berdasarkan kategori.

B5. Member dapat melakukan konfirmasi pembayaran.

B6. Member dapat melakukan testimoni.

B7. Member dapat melihat tentang perusahaan.

B8. Member dapat melihat tentang informasi

Halaman Administrasi :

C1. Admin dapat login.

C2. Admin dapatr mengelola data admin.

C3. Admin dapat mengelola data kategori.

C4. Admin dapat mengelola data produk.

C5. Admin dapat mengelola data pemesanan.

C6. Admin dapat mengelola data biaya kirim.

C7. Admin dapat mengelola konfirmasi.

C8. Admin dapat mengelola data member.

C9. Admin dapat mengelola testimoni.

C10. Admin dapat mencetak laporan.

\section{Use Case Diagram}

\section{Use case Diagram Penjualan Online User}

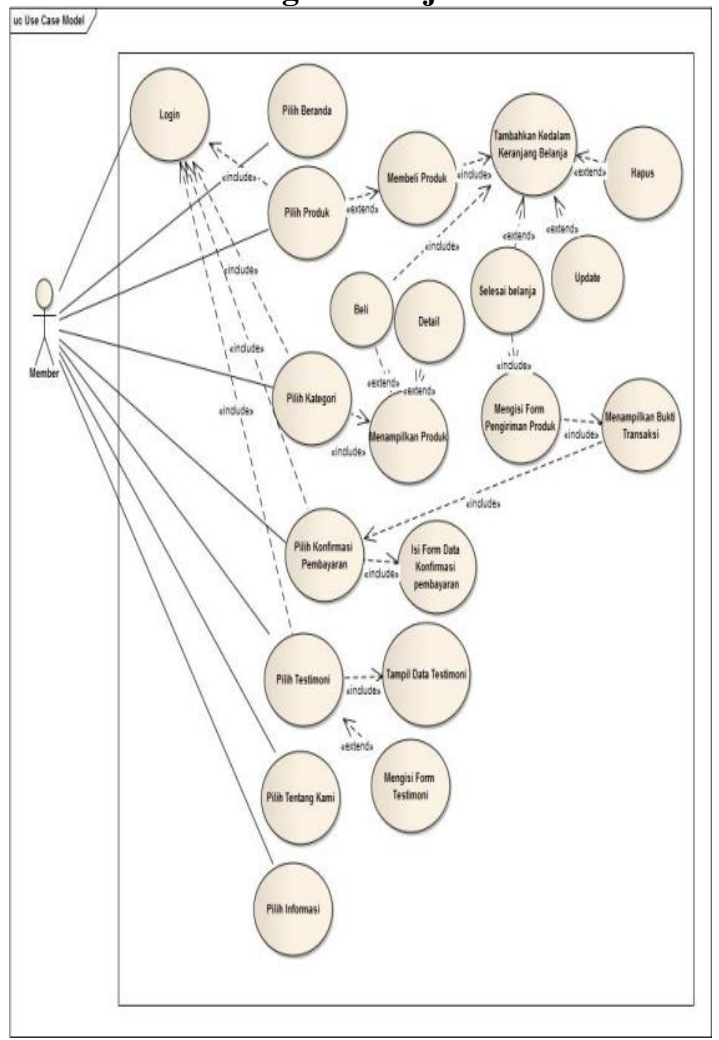

Gambar 2.

Use Case Diagram Penjualan Online User

\section{Use case Diagram Penjualan Online Member}

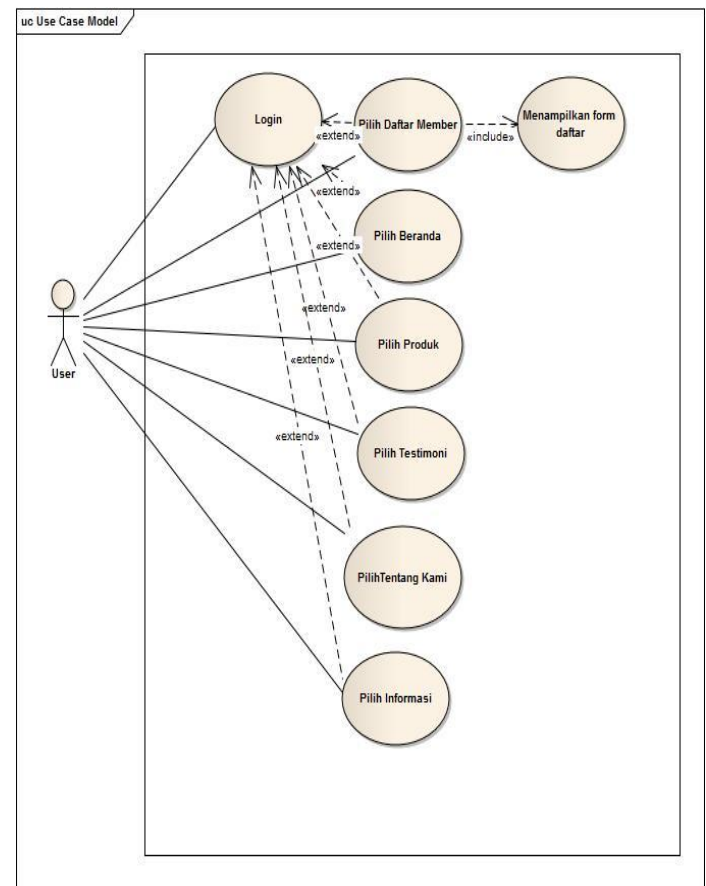

Gambar 3.

Use Case Diagram Penjualan Online Member

\section{Use case Diagram Penjualan Online Admin}

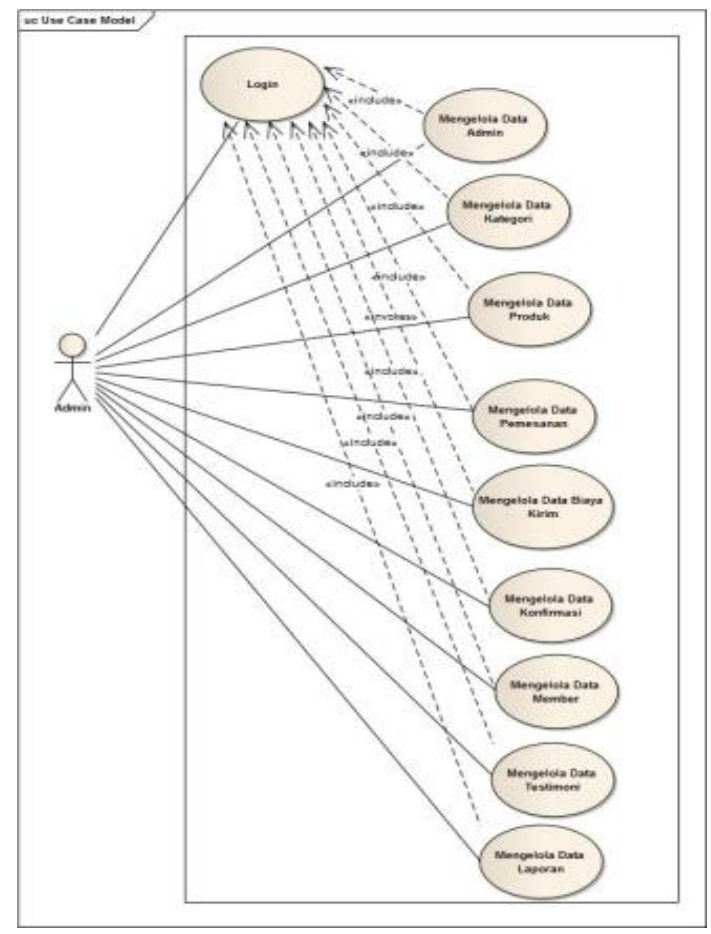

Gambar 4.

Use Case Diagram Penjualan Online Admin 


\section{Activity Diagram Penjualan Online}

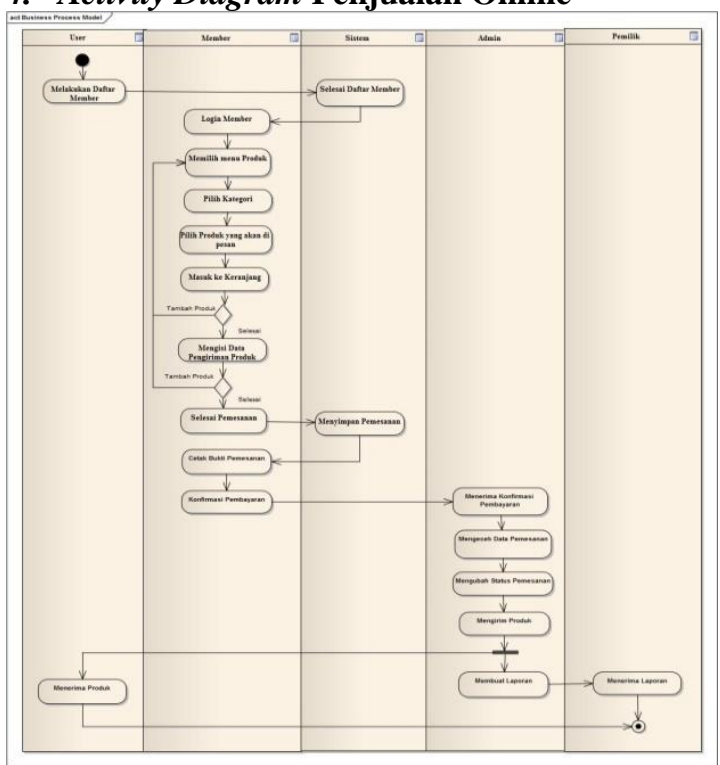

Gambar 4

Activity Diagram Penjualan Online

\section{Desain}

Pada tahapan ini dijelaskan tentang desain database, desain software architecture dan desain interface dari sistem.

\section{Entity Relationship Diagram (ERD)}

Entity Relationship Diagram dalam sistem usulan Sistem Informasi Penjualan Perlengkapan Bayi Berbasis Web Pada Toko Dewa Kembar Baby Shop adalah sebagai berikut:

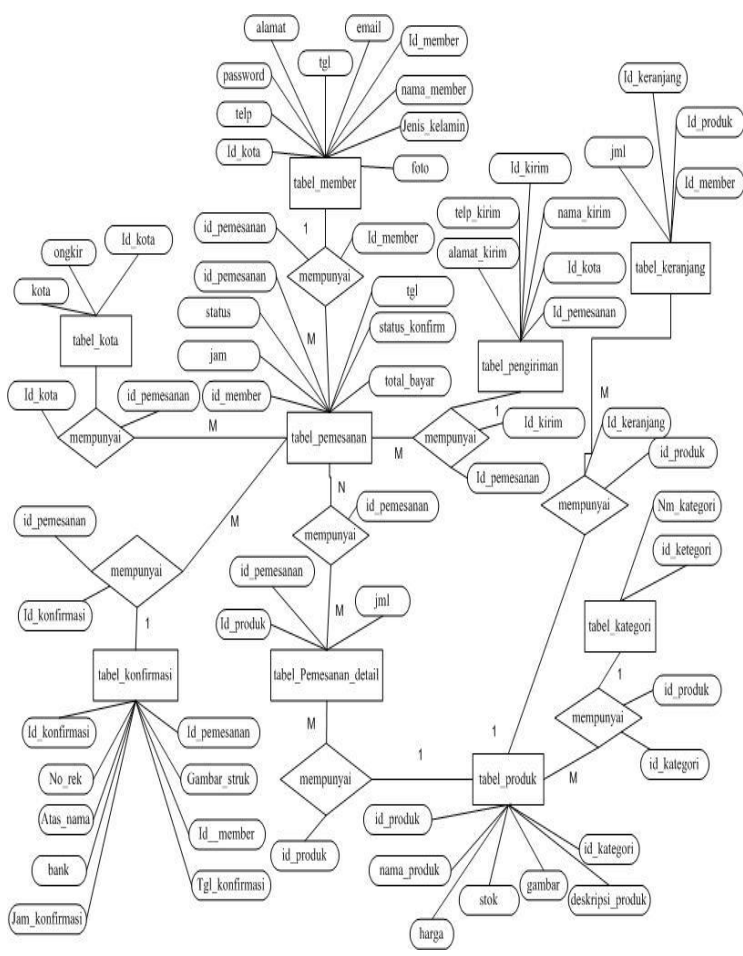

Gambar 5.

Entity Relationship Diagram

\section{Logical Record Structure}

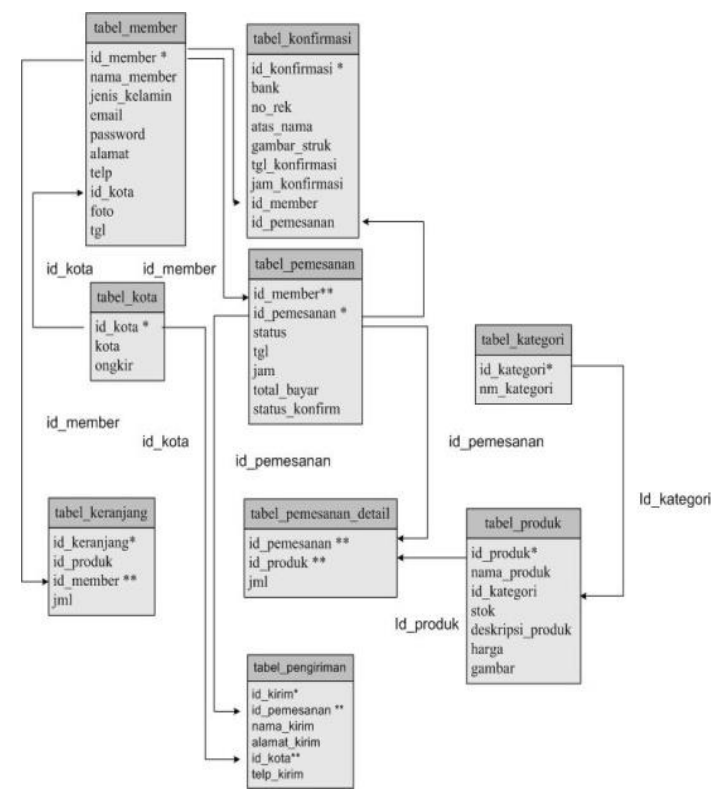

Gambar 6.

\section{Logical Record Structure}

\section{E. Software Architecture}

Pada tahapan ini digambarkan Component Diagram dan Deployment Diagram, berikut ini penggambaran Component Diagram dan Deployment Diagram:

\section{Component Diagram}

Componet Diagram menggambarkan struktur dan hubungan antar komponen piranti lunak, termasuk ketergantungan diantaranya.

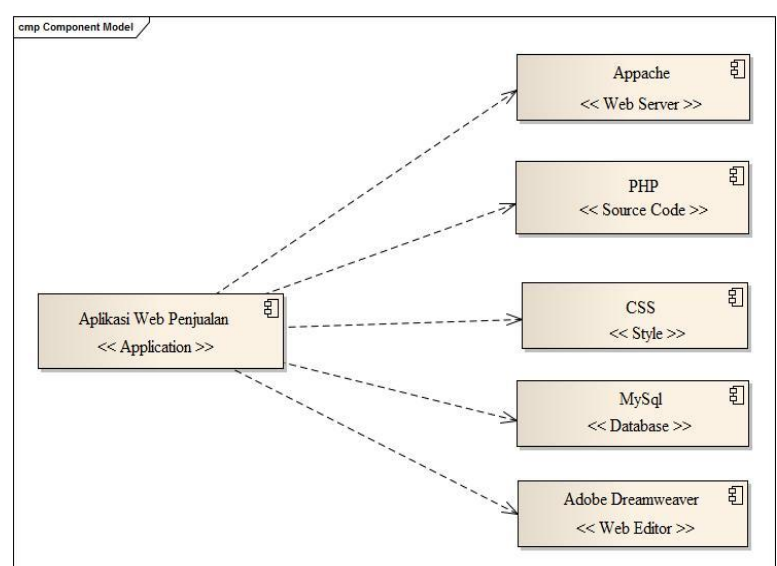

Gambar 7.

Component Daigram

\section{Deployment Diagram}

Deployment Diagram menggambarkan tata letak secara fisik, yang menampakkan bagian-bagian software yang berjalan pada hardware untuk mengimplementasikan sebuah sistem dan keterhubungan antara komponen hardwarehardware. 
Berikut ini beberapa tampilan dari sistem informasi penjualan perlengkapan bayi pada Toko Dewa Kembar Baby Shop:

a. Tampilan Halaman Data Produk

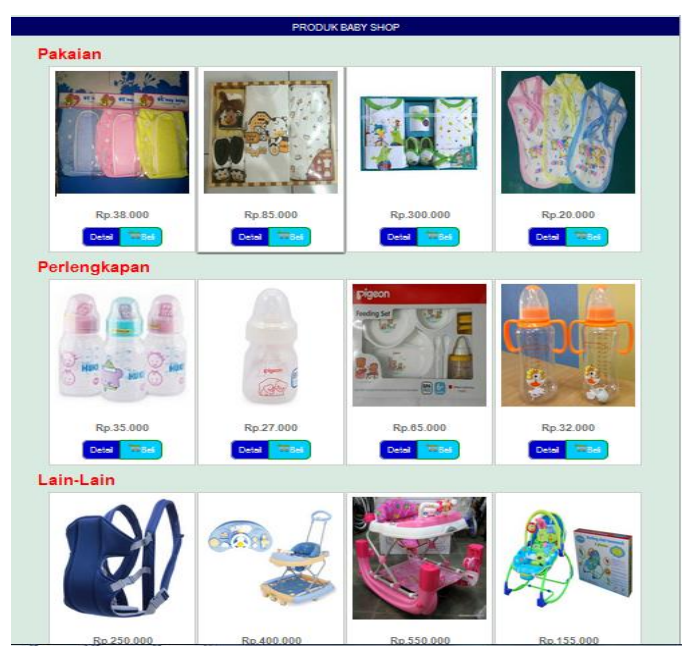

Gambar 8.

Tampilan Data Produk

b. Tampilan Halaman Detail Produk

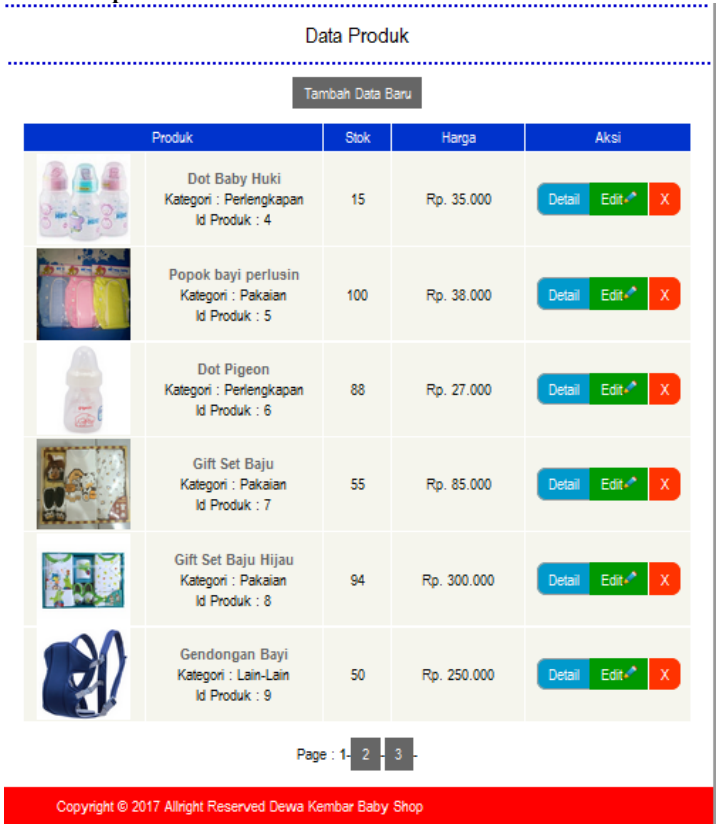

Gambar 9.

Tampilan Halaman Detail Produk

\section{KESIMPULAN}

Penerapan sistem informasi berbasiskan Website ini, sebagai solusi dari permasalahan mengenai penjualan produk pada Toko Dewa Kembar Baby Shop, sehingga dapat mendukung proses penjualan, meningkatkan jumlah pembeli dan mendapatkan pangsa pasar yang lebih luas. Dari pembahasan diatas terdapat beberapa kesimpulan yang dapat dirangkum, yaitu :
1. Aplikasi Toko Dewa Kembar Baby Shop sebagai alat penjualan perlengkapan bayi dapat mempermudah proses transaksi penjualan, member dapat langsung melihat produk dan untuk memilih produk sesuai dengan keinginan secara online tanpa harus datang ke toko.

2. Mempermudah dalam pembuatan laporan penjualan produk dan kekuratan data.

3. Media promosi dan pemesanan lebih meningkat dikarenakan adanya ruang untuk member lebih dapat melihat produk-produk yang dipromosikan

\section{REFERENSI}

Anhar. (2010). Panduan Menguasai PHP dan MySQL Secara Otodidak. Jakarta: Mediakita.

Arief, M. R. (2012). Pemograman Web Dinamis Menggunakan PHP \& MySQL. Yogyakarta. Yogyakarta: Andi Publisher.

Fathansyah. (2012). Buku Text Komputer Basis Data. Bandung: Informatika.

Fowler, M. (2018). UML Distilled (3rd ed.). Addison-Wesley Object Technology Series.

Handita, D. B., Umar, \& Fadillah, U. (2014). Sistem Informasi Penjualan Berbasis Web Pada Usantex. Jakarta, 12(01), 26-33. https://doi.org/10.1111/evo.12175

Irmawati, D. (2011). Pemanfaatan E-Commerce Dalam Dunia Bisnis. Orasi Bisnis, VI(November), 95-112.

Kosasi,S.(2015).Perancangan Sistem Informasi Penjualan Berbasis Web Dalam Memasarkan Mobil Bekas. Jurnal Creative Information Technology, 3(1),114.https://doi.org/10.24076/CITEC.2015V 3I1.61

Mulyanto, A. (2008). Sistem Informasi Konsep \& Aplikasi. Yogyakarta: Pustaka Belajar.

Riyanti, Y., \& Baidawi, T. (2015). Sistem Informasi Penjualan Cat Mobil dan Motor Berbasis Web Pada Toko Karya Indah Bekasi. Journal of Chemical Information and Modeling, 53(9), 1689-1699. https://doi.org/10.1017/CBO97811074153 24.004

Sukamto, R. A. dan M. S. (2014). Rekaya Perangkat Lunak Terstruktur dan Berorientasi Objek. Bandung: Informatika. 